\title{
Al-Madãris
}

VOL. 1, NO. 12020

E-ISSN: 2745-9950

https://journal.staijamitar.ac.id/index.php/almadaris

\section{ETIKA MAHASISWA PROGRAM STUDI PENDIDIKAN FISIKA UNIVERSITAS MALIKUSSALEH TERHADAP DOSEN DITINJAU DARI KEMAMPUAN BERPIKIR KRITIS}

\author{
Fauzan \\ Sekolah Tinggi Agama Islam (STAI) Jamiatut Tarbiyah Lhoksukon \\ fznsyarif84@gmail.com
}

\begin{abstract}
This research aims to examine the correlation between critical thinking and ethics and the contribution of critical thinking to ethics. This research is a field research (field research) with a quantitative approach. Therefore the sample of this study amounted to 61 people. Data collection was carried out by visiting subjects in class during study hours by asking the head of the study program for permission first. Based on the results of the analysis of research data, it can be concluded in this study that they are as follows: 1. Students' critical thinking skills in the 2019-2020 school year are categorized as quite good, this is evidenced by the mean results of 57.87 which are in the "Good Enough" category. ". 2. Student ethics for the 2019-2020 school year are classified as good, this is evidenced by the mean result of 83.21 which is in the "Good" category. 3 . There is a positive relationship between critical thinking skills and student ethics for the 2019-2020 academic year as evidenced by the value of $r$-count $>r$-table, which is $0.331>0.227$ at the $5 \%$ significant level. With a significant value $=0.009,0.05$, the hypothesis $\mathrm{Ha}$ is declared "accepted". In this case the ability to think critically with ethics contributed $10.9 \%$ while the remaining $89.1 \%$ was determined by other variables.
\end{abstract}

Keywords: Critical Thinking Ability, Ethics

$\overline{\text { Al-Madãris, Volume l (1), } 2020}$ 


\section{A. Pendahuluan}

Etika sangat mempengaruhi kehidupan manusia, karena dengan adanya etika membuat manusia berorientasi bagaimana ia menjalankan kehidupannya dalam tindakannya sehari-hari dan bisa membedakan perbuatannya benar atau salah. Tapi dalam kenyataanya etika perlahan-lahan mulai hilang seiring perkembangan jaman, coba kita lihat peristiwa-peristiwa yang terjadi di sekitar kita banyak sekali persoalan yang melanggar etika, hal ini terjadi karena kurangnya kesadaran manusia akan pentingnya etika. Hal inilah yang menyebabkan terjadi berbagai peristiwa yang melanggar moral. Karena itu etika sangatlah penting kita terapkan dalam kehidupan kita agar kita bisa membedakan mana perbuatan yang baik dan mana yang buruk selain itu memberi batasan dalam pergaulan kita dengan sesama agar bisa tercapai kehidupan yang aman dan tentram.Selain itu dapat menciptakan suasana hidup yang aman dan tentram.

Berdasarkan hasil observasi awal yang telah penulis lakukan di prodi pendidikan fisika pada tanggal 19 Januari 2020, penulis mendapatkan informasi, bahwa pembelajaran etika mahasiswa masih kurang bagus, hal ini di tandai dari sikap mahasiswa terhadap dosen, baik itu dosen pembimbing atau pun dosen pengajar. Bila etika menjadi barometer untuk menentukan benar dan salah, maka di perlukan suatu proses untuk mengkritisi perbuatan sebelum mengambil keputusan. Proses tersebut dinamakan berpikir kritis. Berpikir kritis merupakan kegiatan berpikir yang bertujuan untuk membuat keputusan masuk akal tentang apa yang diyakini atau dilakukan. Ini dilakukan melalui lima tahapan penting yaitu: merumuskan permasalahan, menganalisis permasalahan, mengumpulkan informasi, mengevaluasi asumsi dan informasi, serta mengambil kesimpulan. Merumuskan permasalahan yaitu mengatur sedemikian rupa masalah yang sedang dialami dengan cara mencari pernyataan yang jelas dari setiap pertanyaan, mengidentifikasi, merumuskan kriteria untuk mempertimbangkan kemungkinan jawaban dan menjaga kondisi berpikir. Menganalisis permasalahan yaitu berusaha mengetahui informasi dengan baik dengan menggunakan sumber yang memiliki kredibilitas dan menyampaikan sumber yang digunakan. Mengumpulkan informasi dilakukan dengan mencari sumber-sumber yang memiliki kredibilitas yang jelas. Membuat kesimpulan dilakukan setelah melalui tahapan-tahapan diatas. Berpikir kritis merupakan kunci kompetensi yang harus dimiliki seseorang untuk memecahkan masalah (Desmita, 2012: 45).

Berpikir kritis diperlukan untuk mengetahui dan menganalisis perbuatan mana yang seharusnya dilakukan dan perbuatan mana yang harus dijauhi dan ditinggalkan. Berpikir kritis merefleksikan permasalahan secara mendalam, mempertahankan pikiran agar tetap terbuka dari berbagai pendekatan dan perspektif yang berbeda, tidak mempercayai begitu saja informasi-informasi yang datang dari berbagai sumber (lisan atau tulisan), serta berpikir secara reflektif bukan hanya menerima ide-ide dari luar tanpa adanya pemahaman dan evaluasi yang signifikan (Desmita, 2012: 67). Proses berpikir kritis seperti di atas mengondisikan seseorang beretika.

Al-Madãris, Volume 1 (1), 2020 


\section{B. Review Literatur}

Kata etik (atau etika) berasal dari kata ethos (bahasa Yunani) yang berarti karakter, watak kesusilaan atau adat. Sebagai suatu subyek, etika akan berkaitan dengan konsep yang dimilki oleh individu ataupun kelompok untuk menilai apakah tindakan-tindakan yang telah dikerjakannya itu salah atau benar, buruk atau baik. Dalam kehidupan sehari-hari etika sangatlah penting peranannya, karena dengan adanya etika maka dapat mengatur bagaimana manusia dapat bergaul atau bersosialisasi dengan sesamanya. Yang mendasari tumbuh kembangnya etika dalam kehidupan kita adalah agar perbuatan yang tengah kita jalankan sesuai dengan adat atau kebiasaan yang berlaku dan tidak bertentangan dengan hukum yang berlaku.

Salah satu kunci masuk surga adalah berbakti kepada orangtua, dan mempunyai etika baik kepadanya. Rasullah mengecam mereka yang masih mendapati kedua orangtuanya yang masih hidup atau salah satu dari keduanya, namun menyia-nyiakannya begitu saja. Tidak hanya itu, ridha Allah itu tergantung pada ridha orang tua. Begitupun dengan murka-Nya, tergantung pada murka orang tua. Disinilah kita dapat memahami bahwa salah satu kunci untuk mendapatkan ridha Allah adalah dengan berbakti pada orang tua. Beberapa etika terbaik yang disebutkan al-Ghazali adalah mendengarkan ucapannya (Alavi, 2007: 309-319), berdiri ketika keduanya berdiri (untuk menghormati), mematuhi perintahnya, tidak mendahuluinya ketika berjalan, tidak mengabaikan panggilannya, berusaha mengejar ridhanya, rendah hati kepada keduanya, ikhlas dalam berbakti, meneduhkan pandangan, tidak bermuka masam, dan meminta izinnya ketika hendak bepergian. Etika tersebut menyadarkan beberapa akhlak mulia yang seharusnya kita terapkan seterusnya kepada orang tua dimanapun berada. Terlebih dalam berusaha keras untuk mendapatkan ridha kedua orang tua. Sebab bagaimanapun juga, ridha orang tua inilah yang berpengaruh besar dalam kesuksesan kita. Bila ingin sukses, berbaktilah kepada orang tua. Dan jadikan orang tua sebagai alasan terkuat untuk sukses. Karena niat yang baik dan diridhai orang tua akan menjadikan mudah bagi Allah untuk memeberikan kesuksesan yang kita inginkan.

Diantara etika terhadap diri sendiri; 1) jujur dan terbuka serta tidak memberikan informasiyang tidak benar; 2) bertindak dengan penuh kesungguhan dan ketulusan; 3) menghindari konflik kepentingan pribadi, kelompok, maupun golongan; 4) berinisiatif untuk meningkatkan kualitas pengetahuan, kemampuan, keterampilan, dan sikap; 5) memiliki daya juang yang tinggi; 6) memelihara kesehatan jasmani dan rohani; 7) menjaga keutuhan dan keharmonisan keluarga; 8) berpenampilan sederhana, rapih, dan sopan (al-Ghazali, 1980: 109-115).

\section{Metodelogi}

Penelitian ini merupakan penelitian lapangan (field research) dengan pendekatan kuantitatif. Populasi dalam penelitian ini adalah seluruh mahasiswa prodi pendidikan fisika tahun ajaran 2019-2020 sebanyak 61 siswa. Dikarenakan jumlah populasi kurang dari 100 orang, maka penentuan sampel dilakukan dengan menjadikan seluruh jumlah populasi sebagai sampel. Dengan demikian

Al-Madãris, Volume 1 (1), 2020 
sampel penelitian ini berjumlah 61 orang. Pengumpulan data dilakukan dengan mendatangi subjek di kelas saat jam belajar dengan meminta izin ketua program studi terlebih dahulu.

Instrumen yang digunakan adalah skala berpikir kritis yang disusun sendiri dengan mengacu pada teori berpikir kritis dengan melibatkan 5 aspek yaitu: merumuskan permasalahan, menganalisis permasalahan, mengumpulkan informasi, mengevaluasi asumsi dan informasi, serta mengambil kesimpulan. Demikian juga dengan etika menggunakan skala etika yang disusun sendiri dengan mengacu pada Ahmad Tafsir (Ahmad Tafsir, 2010: 98) yang mencakup empat aspek yaitu: etika kepada Allah, etika kepada sesama, etika kepada diri sendiri, dan etika kepada lingkungan. Selanjutnya data dianalisis dengan menggunakan teknik product moment dengan bantuan Program SPSS versi 17.

\section{Hasil Penelitian}

1. Subjek Penelitian

Dari 61 orang mahasiswa prodi pendidikan fisika diperoleh rincian data subjek penelitian sebagai berikut:

Tabel 1. Deskripsi Subjek Penelitian

\begin{tabular}{|c|c|c|c|}
\hline Kelas & \multicolumn{2}{|c|}{ Jenis Kelamin } & Rentang \\
\hline & Laki-laki & Perempuan & \\
\hline $\mathrm{Al}$ & 12 & 17 & $18-19$ \\
\hline A2 & 13 & 19 & \\
\hline Jumlah & 25 & 36 & \\
\hline
\end{tabular}

Berdasar Tabel 1, jumlah perempuan pada kelas Al lebih banyak dibanding laki-laki. Ini ada kaitannya dengan tingkat prestasi akademik siswa, dimana siswa perempuan lebih baik dalam prestasi akademik dibanding lakilaki. Dalam hal peluang drop out di Perguruan Tinggipun demikian, perempuan berpeluang lebih kecil dibanding laki-laki (Woolfolk, 2008: 128). Sebagaimana ditunjukkan dalam sejumlah penelitian bahwa salah satu yang menyebabkan perempuan lebih baik dalam prestasi akademik dan lebih kecil dalam peluang drop out dikarenakan perempuan terbukti memiliki motivasi belajar lebih tinggi dibanding laki-laki, dan perempuan juga lebih beragam dalam menggunakan strategi-strategi pembelajaran, yang disesuaikan dengan karakteristik materi (Alsa, 2005: 97). Motivasi dan strategi pembelajaran merupakan dua faktor penentu dalam keberhasilan pendidikan (prestasi akademik).

\section{Validitas dan Reliabilitas Instrumen Penelitian}

Hasil uji validitas untuk skala kemampuan berpikir kritis menunjukkan bahwa dari 19 item terdapat 18 item yang valid, dan 1 item yang tidak valid. Item yang valid memiliki korelasi aitem dengan skor total yang merentang antara 0,229-0,660 dengan tingkat reliabilitas 0,803. Adapun hasil uji validitas untuk skala Etika mahasiswa menunjukkan bahwa dari 30 item terdapat 25 item

$\overline{\text { Al-Madãris, Volume l (1), } 2020}$ 
yang valid, dan 5 item yang tidak valid. Item yang valid memiliki korelasi item dengan skor total yang merentang antara 0,294-0,544 dengan tingkat reliabilitas 0,764 . Dengan demikian kedua skala penelitian ini dinyatakan valid dan reliabel secara statistik.

\section{Normalitas dan Linieritas Data Penelitian}

Hasil uji prasyarat terhadap data penelitian menunjukkan bahwa data penelitian dinyatakan normal dengan nilai 0,074 dan $\mathrm{p}=0,001$. Demikian juga hasil uji linieritas menunjukkan bahwa data penelitian ini dinyatakan linier dengan nilai $\mathrm{F}=0,870$ dan $\mathrm{p}=0,618$.

\section{Hasil Uji Korelasi Kemampuan Berpikir Kritis dan Etika}

Uji korelasi dengan menggunakan teknik product moment diperoleh nilai $\mathrm{r}=331$ dengan $\mathrm{p}=0,009$. Ini artinya bahwa terdapat korelasi positif yang signifikan

\section{Deskripsi Data Penelitian}

Deskripsi data penelitian secara keseluruhan ditunjukkan pada Tabel 2.

Tabel 2. Deskripsi Data Penelitian ( $N=61)$

\begin{tabular}{lcccc}
\hline \multirow{2}{*}{ Variabel } & \multicolumn{4}{c}{ Empirik } \\
\cline { 2 - 5 } & Min & Max & Mean & SD \\
\hline Kemampuan berfikir Kritis & 47 & 68 & 57,87 & 4,945 \\
\hline Al-Akhlaq al-Karimah & 69 & 96 & 83,21 & 4,619 \\
\hline
\end{tabular}

Deskripsi data di atas diperkuat oleh kategorisasi berikut untuk mengetahui posisi subjek dalam penelitian. Hasil kategorisasi sebagaimana ditunjukkan pada Tabel 3.

Tabel 3. Kategori Subjek berdasar Variabel Berfikir Kritis

\begin{tabular}{cccc}
\hline Skor & Kategori & Frekuensi & Presentasi \\
\hline 65 ke atas & Sangat Baik & 5 & $8 \%$ \\
\hline $60-64$ & Baik & 20 & $33 \%$ \\
\hline $55-59$ & Cukup Baik & 22 & $36 \%$ \\
\hline $50-54$ & Kurang Baik & 11 & $18 \%$ \\
\hline 49 ke bawah & Sangat Kurang Baik & 3 & $5 \%$ \\
\hline
\end{tabular}

Mengacu pada Tabel 3, terdapat 5 orang (5\%) siswa yang memiliki kemampuan berpikir kritis sangat baik dan 20 orang (33\%) yang memiliki kemampuan berpikir kritis baik. Sementara kemampuan berpikir kritis terbanyak terdapat 22 orang (36\%). Sementara siswa yang memiliki kemampuan berpikir kritiscukup baik dan kurang baik adalah sebanyak 11 orang (18\%) dan 3 orang (5\%). Dengan demikian secara keseluruhan siswa sebagai subjek penelitian ini memiliki kemampuan berpikir kritis Cukup Baik. Selanjutnya hasil kategorisasi variabel etika ditunjukkan pada Tabel 4. 
Tabel 4. Kategori Subjek berdasar Variabel Etika

\begin{tabular}{cccc}
\hline Skor & Kategori & Frekuensi & Persentase \\
\hline 90 ke atas & Sangat Baik & 5 & $8 \%$ \\
\hline $85-89$ & Baik & 20 & $33 \%$ \\
\hline $81-84$ & Cukup Baik & 18 & $30 \%$ \\
\hline $76-80$ & Kurang Baik & 16 & $26 \%$ \\
\hline 75 ke bawah & Sangat Kurang Baik & 2 & $3 \%$ \\
\hline
\end{tabular}

Mengacu pada Tabel 4, terdapat 5 orang (8\%) siswa yang memiliki etika sangat baik dan 20 orang (33\%) yang memiliki etika baik. Sementara siswa yang memiliki akhlakul karimah cukup baik, kurang baik, dan sangat kurang baik adalah sebanyak 18 orang (30\%), 16 orang (26\%), dan 2 orang (3\%). Dengan demikian secara keseluruhan siswa sebagai subjek penelitian ini memiliki etika baik.

\section{E. Pembahasan}

Hasil analisis deskriptif dalam penelitian ini dapat dilihat bahwa kemampuan berpikir kritis termasuk kedalam kategori cukup baik. Hal ini dapat dibuktikan dengan skor rata-rata (mean) dari keseluruhan skor responden adalah 57,87 yang berada pada skor 55-59. Sehingga dapat dinyatakan bahwa kemampuan berpikir kritis termasuk dalam kategori "Cukup Baik". Kemampuan berpikir kritis adalah kemampuan dimana siswa dapat berpikir sesuatu hal apapun, yang harusnya dilakukan oleh siswa tersebut tanpa adanya melanggar norma-norma ajaran agama Islam. Kemampuan berpikir kritis sangat diperlukan agar mahasiswa dapat selalu menganalisis, memilih dan melakukan perbuatan-perbuatan yang selalu selaras dengan al-qur'an dan sunnah Nabi Muhammad saw.

Hasil analisis deskriptif dalam penelitian ini dapat dilihat bahwa etika mahasiswa termasuk dalam kategori baik. Hal ini dapat dibuktikan dengan skor rata-rata (mean) dari keseluruhan skor responden adalah 83,21 yang berada pada skor 85-89. Sehingga dapat dinyatakan bahwa etika mahasiswa prodi pendidikan fisika tahun ajaran 2019-2020 termasuk dalam kategori "Baik".

Etika adalah perbuatan terpuji menurut pandangan akal dan syariat Islam. Etika adalah suatu sistem nilai yang mengatur pola sikap dan tindakan manusia diatas bumi yang sesuai dengan ajaran agama Islam dengan menggunakan pedoman Alquran dan Sunnah Rasul sebagai sumber nilai serta ijtihad sebagai metode berpikir islami. Sehingga dalam hal ini dibutuhkan faktor pendorong yang kuat baik dari faktor internal yang berasal dari diri siswa tersebut maupun faktor eksternal yang berasal dari selain diri mahasiswa tersebut. Etika dapat membuat mahasiswa mendapatkan kehidupan yang nyaman, mendapatkan pahala dari Allah swt, mendapatkan banyak teman, menjalankan syariat Islam dan lain sebagainya. Apabila mahasiswa memiliki

$\overline{\text { Al-Madãris, Volume l (1), } 2020}$ 
etika yang tinggi maka akan menghantarkan pada buah dari perbuatan baik yaitu surga-Nya Allah swt yang kekal dan abadi selama-lamanya.

Mahasiswa yang memiliki etika yang tinggi akan selalu berusaha melaksanakan segala perbuatannya dengan perbuatan-perbuatan yang baik dan tidak senonoh (kurang baik) dimanapun dan di waktu kapanpun siswa tersebut berada. Baik akhlak siswa terhadap Allah swt sebagai sang Maha Pencipta, akhlak.

Hasil penelitian ini menunjukkan terdapat hubungan positif antara kemampuan berpikir kritis dengan etika mahasiswa di kelas Al dan A2. Hal ini dibuktikan berdasarkan hasil SPSS korelasi product moment yang menunjukkan bahwa nilai rhitung > rtabel yaitu sebesar 0,331 >0,227 dengan nilai signifikan = $0,009<0,05$, maka dapat disimpulkan bahwa korelasi dari kemampuan berpikir kritis dengan etika "berdistribusi normal". Dalam hal ini kemampuan berpikir kritis dengan etika mahasiswa memberikan kontribusi sebesar 10,9\% yang dapat diartikan bahwa kemampuan berpikir kritis dengan etika mempunyai hubungan antara keduanya. Sedangkan sisanya $89,1 \%$ dijelaskan dengan faktor lain atau variabel lain yang tidak diteliti dalam penelitian ini.

\section{F. Kesimpulan}

Berdasarkan hasil analisis data penelitian, maka dapat disimpulkan dalam penelitian ini yaitu sebagai berikut:

1. Kemampuan berpikir kritis mahasiswa tahun ajaran 2019-2020 tergolong dalam kategori cukup baik, hal ini dibuktikan dengan hasil mean sebesar 57,87 yang berada dalam kategori "Cukup Baik".

2. Etika mahasiswa maha siswa tahun ajaran 2019-2020 tergolong baik, hal ini dibuktikan dengan hasil mean sebesar 83,21 berada dalam kategori "Baik".

3. Terdapat hubungan positif antara kemampuan berpikir kritis dengan etika mahasiswa tahun ajaran 2019-2020 dengan dibuktikan nilai rhitung> rtable yaitu sebesar 0,331 > 0,227 pada taraf signifikan 5\%. Dengan nilai signifikan =0,009, 0,05 maka hipotesis $\mathrm{Ha}$ dinyatakan "diterima". Dalam hal ini kemampuan berpikir kritis dengan etika memberikan kontribusi sebesar 10,9\% sedangkan sisanya 89,1\% ditentukan dengan variabel lain.

\section{BIBLIOGRAFI}

Ahmad Tafsir. (2010). Filsafat Pendidikan Islam. cet ke-IV. Bandung: Rosdakarya Ajat Rukajat. (2018). Pendekatan Penelitian Kuantitatif. Yogyakarta: Deepublish. Alavi, H. R. (2007). Al-Ghazāli on Moral Education. Journal of Moral Education, 36(3), 2007. pp: 309-319.

Al-Ghazali, H., Abu. (1980). Ihya'Ulumuddin, juz VII-IX (Vol. Juz VII-IX). Beirut: Daarul Fikr.

Alec Fisher. (2008). Berpikir Kritis, Sebuah Pengantar. Jakarta: Gelora Aksara Pratama

$\overline{\text { Al-Madaris, Volume l (1), } 2020}$ 
Al-Jawziyyah, I. Q. (1977). I'lām al-Muwaqqi'in 'an Rabb al-'Ālamīn. Beirut: Dār alFikr.

Alsa, A. (2005). Program Belajar, Jenis Kelamin, Belajar Berdasar Regulasi Diri dan Prestasi Belajar Pada Siswa SMA di Yogyakarta. Disertasi (tidak dipublikasikan). Sekolah Pascasarjana Universitas Gadjah Mada.

Budi Susetyo. (2012). Statistika Untuk Analisis Data Penelitian. Bandung: Reflika Aditama.

Desmita. (2012). Psikologi Perkembangan Peserta Didik. Bandung: Remaja Rosdakarya.

Marcel Boisard. (1980). Humanisme dalam Islam. Jakarta: Bulan Bintang.

Muhammad Iqbal.(2010). Etika Politik Qur'ani: Penafsiran M. Quraish Shihab Terhadap Ayat-ayat Kekuasaan. Medan: IAIN Press.

Nurullah, A. S. (2008). Globalisation as a Challenge to Islamic Cultural Identity. The International Journal of Interdisciplinary Social sciences. 3(6), 2008. pp. 45-52

Puguh Suharso. (2009). Metode Penelitian Kuantitatif Untuk Busnis: Pendekatan Filosofis dan Praktis. Jakarta: Indeks.

Woolfolk. (2018). Educational Psychology Active Learning Edition Tenth Edition. Boston: Allya \& Baco. 